\title{
PERBANDINGAN PRINCIPAL AXIS FACTORING DAN MAXIMUM LIKELIHOOD DALAM MENENTUKAN FAKTOR DOMINAN YANG MEMPENGARUHI PEMBELAJARAN NAHWU SHOROF (STUDI KASUS PONDOK PESANTREN ROUDLOTUL MUTA'ALLIMIN PUTRI)
}

\section{Comparison Of Principal Axis Factoring And Maximum Likelihood In Determining Dominant Factors Affecting Nahwu Shorof's Learning (Case Study of Roudlotul Muta'allimin Putri Islamic Boarding School)}

\author{
Tanwirotul Khusna*1, Rachmadania Akbarita ${ }^{2}$, Risang Narendra ${ }^{3}$ \\ ${ }^{1,2,3}$ Prodi Matematika, FIE, Universitas Nahdlatul Ulama Blitar \\ Jln. Masjid No 22, Kauman Kepanjen Kidul, Blitar, 66117, Indonesia \\ Corresponding author e-mail: ${ }^{1 *}$ sinaqumilaila@gmail.com
}

\begin{abstract}
Abstrak
Penelitian ini membahas tentang penentuan faktor dominan yang mepengaruhi keberhasilan belajar nahwu shorof di Pondok Pesantren Roudlotul Mutaalimin putri Desa Minggirsari. Penentuan faktor dominan dilakukan untuk memaksimalkan kualitas pendidikan dipondok pesantren tersebut, sehingga minat calon peserta didik semakin banyak. Pada penelitian ini, dibandingkan 2 metode ekstraksi, yaitu metode Principal Axis Factoring dan Maximum Likelihood. Variabel-variabel yang mempengaruhi keberhasilan belajar nahwu shorof ada 13, yaitu lingkungan alam(P1), lingkungan sosial(P23), kurikulum (P49), program madrasah (P1012), sarana dan fasilitas (P1315), tenaga pengajar (P1619), kondisi fisiologis (P2021), kondisi panca indra (P22), minat belajar (P2325), kecerdasan santri (P26), bakat santri (P27), motivasi santri (P28), kemampuan kognitif(P2930). Tujuan penelitian ini, yaitu untuk mengetahui metode ekstraksi yang paling tepat digunakan dalam analisis faktor. Hasil dari penelitian ini adalah metode Maximum Likelihood lebih tepat digunakan dari pada metode Principal Axis Factoring, karena memiliki nilai RMSE (Root Mean Squared Error) lebih kecil.
\end{abstract}

Kata Kunci : Analisis Faktor, Principal Axis Factoring, Maximum Likelihood, Faktor Dominan, Nahwu Shorof

\begin{abstract}
This study discusses the dominant factors that influence the success of learning nahwu shorof at the Roudlotul Mutaalimin Islamic Boarding School for the daughter of Minggirsari Village. Determining the dominant factor is done to maximize the quality of education in the boarding school, so that the interest of prospective students is increasing. In this study, two extraction methods were compared, namely the Principal Axis Factoring and Maximum Likelihood methods. There are 13 variables that affect the success of nahwu shorof learning, namely the natural environment (P1), social environment (P23), curriculum (P49), madrasa program (P1012), facilities and facilities (P1315), teaching staff (P1619), condition of physiological (P2021), condition of the five senses (P22), interest in learning (P2325), intelligence of students (P26), student talent (P27), motivation of students (P28), cognitive ability (P2930). The purpose of this study, namely to determine the most appropriate extraction method used in the analysis. The result of this study is the Maximum Likelihood method which is more appropriate than the Principal Axis Factoring method, because it has a smaller RMSE (Root Mean Squared Error) value.
\end{abstract}

Keywords: Factor Analysis, Principal Axis Factoring, Maximum Likelihood, Dominant Factor, Nahwu Shorof

Article info:

Submitted:13 ${ }^{\text {th }}$ August 2021 Accepted: $26^{\text {th }}$ November 2021

How to cite this article:

T. Khusna, R. Akbarita, and R. Narendra, PERBANDINGAN PRINCIPAL AXIS FACTORING DAN MAXIMUM LIKELIHOOD DALAM MENENTUKAN FAKTOR DOMINAN YANG MEMPENGARUHI PEMBELAJARAN NAHWU SHOROF (STUDI KASUS PONDOK PESANTREN ROUDLOTUL MUTA'ALLIMIN PUTRI)”, BAREKENG: J. Il. Mat. \& Ter., vol. 15, no. 04, pp. 785-796, Dec. 2021.

Copyright (C 2021 Tanwirotul Khusna, Rachmadania Akbarita, Risang Narendra 


\section{PENDAHULUAN}

Seiring perkembangan zaman, persaingan pendidikan dikalangan pondok pesantren terus meningkat. Masing-masing lembaga pondok pesantren senantiasa meningkatkan kualitas pendidikannya untuk menarik minat para calon peserta didik baru, hal ini dikarenakan baik buruknya kualitas pendidikan selalu menjadi pertimbangan utama bagi orang tua dalam menentukan pendidikan yang terbaik bagi putra putrinya [1]. Unit pendidikan di Pondok Pesantren Roudlotul mutaallimin yang dijadikan sebagai program unggulan adalah pembelajaran diniyah pada mata pelajaran nahwu shorof. Menurut [2] faktor-faktor yang dipertimbangkan untuk mencapai keberhasilan pembelajaran nahwu shorof ada 13 yaitu lingkungan alam, lingkungan sosial, kurikulum, program madrasah, sarana dan fasilitas, tenaga pengajar, kondisi fisiologis, kondisi panca indra, minat belajar, kecerdasan santri, bakat santri, motivasi santri dan kemampuan kognitif. Dengan Jumlah faktor pendukung yang banyak, maka perlu diketahui faktor apa saja yang paling mendominasi keberhasilan belajar nahwu shorof sehingga upaya peningkatan faktor pendukung lebih maksimal dan minat calon peserta didik baru untuk mendaftarkan diri semakin banyak.

Berdasarkan permasalahan tersebut penulis bermaksud untuk melakukan penelitian mengenai faktorfaktor yang paling mendominasi keberhasilan belajar nahwu shorof di Pondok Pesantren Roudlotul Mutaallimin dengan analisis faktor. Menurut [3] Analisis faktor merupakan suatu usaha penyederhanaan kerumitan dengan meringkas kerumitan yang sangat banyak unsurnya kedalam faktor yang sederhana dan mudah dipahami. Adapun metode ekstraksi yang digunakan adalah metode Principal Axis Factoring dan Maximum Likelihood. Metode Principal Axis Factoring hampir sama dengan metode analisis komponen utama kecuali matrik korelasi diagonal diganti dengan sebuah estimasi indikator kebersamaan [4]. Metode Maximum Likelihood merupakan suatu model ekstraksi faktor yang menghasilkan estimasi parameter yang paling memungkinkan untuk medapatkan matrik korelasi observasi [5].

Penelitian ini merupakan pengembangan dari penelitian-penelitian sebelumnya, seperti penelitian yang dilakukan oleh Ruth.E.D. Nadeak pada tahun 2016 yang membandingkan 2 metode ekstraksi yaitu Principal Component Analysis dan Maximum Likelihood dalam menentukan suatu faktor yang memengaruhi pemilihan alat kontrasepsi di desa X. Hasil dari penelitian tersebut menunjukkan bahwa metode Maximum Likelihood lebih tepat digunakan. Selain itu penelitian ini juga merupakan pengembangan dari penelitian yang dilakukan oleh Nadine Krisne Maulidini pada tahun 2019 yang juga membandingkan 2 metode yaitu Principal Axis Factoring dan Principal Component Analysis dalam menentukan suatu faktor kepuasan konsumen pengguna sepatu X. Hasil dari penelitian tersebut menunjukkan bahwa metode Principal Component Analysis lebih tepat digunakan. Penelitian kali ini akan membandingkan 2 metode yaitu Principal Axis Factoring dan Maximum Likelihood. Walaupun jika didasarkan kedua penelitian diatas sudah jelas bahwa metode Principal Axis Factoring lebih rendah dari pada kedua metode lainnya, namun pada tahun 2021 terdapat penelitian yang dilakukan oleh Hepi Wahyuningsih dan Dyna Rahayu Suci Pertiwi yang lebih memilih metode Principal Axis Factoringdari pada metode yang lain. Menurut [6] metode Principal Axis Factoring lebih mampu mengetahui sebuah konstruk dari sebuah alat ukur. Oleh karena itu peneliti ingin mengetahui metode mana yang lebih unggul antara Principal Axis Factoring dan Maximum Likelihood.

\section{METODE PENELITIAN}

\subsection{Sumber dan Proses Pengumpulan Data}

Data yang digunakan dalam penelitian kali ini adalah data primer yang diperoleh melalui pembagian kuesioner kepada santri putri Pondok Pesantren Roudlotul Mutaallimin. Pengambilan data tersebut dilakukan pada bulan April 2021. Proses pengambilan data pada penelitian ini diawali dengan penentuan variabel penelitian. Pada penelitian kali ini variabel ditentukan berdasarkan penelitian [2] yang mengatakan bahwa faktor-faktor yang mempengaruhi keberhasilan belajar nahwu shorof ada 13 yaitu lingkungan alam(P1), lingkungan sosial (P23), kurikulum(P49), program madrasah (P1012), sarana dan fasilitas (P1315), tenaga pengajar(P1619), kondisi fisiologis(P2021), kondisi panca indra (P22), minat belajar (P2325), kecerdasan santri(P26), bakat santri(P27), motivasi santri(P28) dan kemampuan kognitif (P2930). Kemudian variabel tersebut disusun menjadi sebuah kuesioner yang berjumlah 30 item pernyataan. Setelah kuesioner terbentuk, kuesioner tersebut divalidasi oleh 2 orang validator. Setelah kuesioner dinyatakan valid kemudian dilakukan uji coba instrumen dengan pembagian kuesioner kepada 30 responden. Dari data yang diperoleh kemudian dilakukan uji validitas dan reliabilitas. Setelah seluruh pernyataan dinyatakan valid dan reliabel, kemudian 
dilakukan pengambilan data dengan pembagian kuesioner kepada 75 responden. Jumlah tersebut diperoleh melalui rumus slovin dengan metode pengambilan sampel berupa probability sampling.

\subsection{Metode Analisis}

Tahapan-tahapan analisis data dalam penelitian ini adalah sebagai berikut:

1. Uji kelayakan data melalui persamaan berikut:

a. Uji KMO (Keyser-Mayer Olkin)

$$
\mathrm{KMO}=\frac{\sum \sum \mathrm{r}^{2}{ }_{\mathrm{ij}}}{\sum \sum \mathrm{r}^{2}{ }_{\mathrm{ij}}+\sum \sum \mathrm{a}^{2}{ }_{\mathrm{ij}}}
$$

dengan $r^{2}{ }_{i j}$ adalah Koefisien Korelasi dan $a^{2}{ }_{i j}$ adalah Koefisien Korelasi Parsial

b. Uji MSA (Measure of sampling Adequacy)

$$
\text { MSA }=\frac{\sum i \neq j r^{2} i j}{\sum i \neq j r^{2} i j+\sum i \neq j a^{2} i j}
$$

dengan $\mathrm{r}_{\mathrm{ij}}$ adalah koefisien korelasi antara variabel $i$ dan $j$ dan $a_{i j}$ adalah koefisien korelasi parsial antara variabel $i$ dan $j$

c. Uji Bartlet test of sphrericity

$$
\left(-(n-1)-\frac{2 p+5}{6}\right) \operatorname{In}|R|
$$

\section{Ekstraksi Faktor}

a. Metode Principal Axis Factoring

Menurut [7] tahapan-tahapan ekstraksi faktor pada metode ini diawali dengan pembentukan matrik varian kovarian, kemudian menentukan invers matrik tersebut, dari diagonal utama matriks invers kemudian menentukan penduga awal dengan persamaan

$$
\mathrm{h}_{\mathrm{i}}^{2 *}=\mathrm{s}_{\mathrm{ii}}-\frac{1}{\mathrm{~s}^{\mathrm{ii}}}
$$

kemudian penduga awal tersebut di subtitusikan pada matrik varian kovarian, setelah terbentuk matrik baru kemudian dicari nilai eigen dan vector eigen. Dari nilai eigen dan vector eigen tersebut kemudian ditentukan nilai korelasi variabel terhadap faktor (Loading Factor) melalui persamaan

$$
\ell_{\mathrm{ii}}=\sqrt{\lambda} \mathrm{e}
$$

dari nilai korelasi tersebut kemudian dihitung nilai komunalitas yang merupakan penjumlahan kuadrat dari masing-masing nilai korelasi tersebut.

b. Metode Maximum Likelihood

Menurut [8] tahapan-tahapan ekstraksi faktor pada metode ini diawali dengan pembentukan matrik varian kovarian, kemudian menentukan nilai eigen dan vector eigen dari matrik tersebut, dengan nilai kedua nilai tersebut kemudian menentukan nilai loading factor melalui persamaan (5), dari nilai tersebut kemudian ditentukan nilai komunalitas yang merupakan penjumlahan kuadrat dari masingmasing nilai loading factor tersebut, kemudian dari nilai komunalitas tersebut ditentukan penduga awal melalui persamaan

$$
\psi_{\mathrm{i}}=\mathrm{S}_{\mathrm{ii}}-\mathrm{h}_{\mathrm{i}}^{2 * *}
$$

Kemudian nilai tersebut disubtitusikan ke diagonal utama matrik varian kovarian dan ditentukan nilai eigen dan vector eigen, dari kedua nilai tersebut kemudian ditentukan nilai loading factor melalui persamaan (5), kemudian dihitung nilai komunalitas yang merupakan penjumlahan kuadrat dari masing-masing nilai loading factor tersebut.

3. Penentuan Jumlah Faktor

Menurut [9] terdapat beberapa cara yang dapat digunakan untuk penentuan jumlah faktor, seperti penentuan berdasarkan apriori, penentuan berdasarkan eigenvalue, penentuan berdasarkan screeplot, dan penentuan berdasarkan presentase varian, namun pada penelitian ini penentuan jumlah faktor dilakukan berdasarkan nilai eigenvalue yang $\geq 1$.

4. Rotasi Faktor

Rotasi faktor merupakan salah satu proses dalam analisis faktor yang dilakukan dengan cara merotasi factor loading . Rotasi faktor ini bertujuan untuk mentransformasi matrik faktor menjadi matrik yang lebih sederhana yang lebih mudah untuk diinterpretasikan [10].

$$
\mathrm{L}^{\prime}=\mathrm{L} \Gamma
$$


dengan $L$ merupakan matrik loading factor sebelum dirotasi, $\Gamma$ merupakan matrik rotasi dan L' merupakan matrik loading factor sebelum dirotasi.

5. Interpretasi Faktor

Interpretasi faktor dilakukan dengan cara melihat nilai loading factor setiap variabel terhadap faktor. Variabel yang memiliki nilai loading factor tertinggi pada faktor yang sama, maka variabel tersebut merupakan bagian dari faktor tersebut [11].

6. Penamaan Faktor

Menurut [12] terdapat dua cara yang dapat digunakan untuk menamai faktor, yaitu:

Menamai faktor dengan nama yang dapat mewakili nama-nama variabel yang membentuk faktor tersebut. Manamai faktor berdasarkan variabel yang memiliki nilai faktor loading tertinggi. Hal ini dilakukan jika tidak memungkinkan memberi nama yang dapat mewakili variabel-variabel pembentuk faktor tersebut.

7. Uji Ketepatan Metode

Menurut [13] tujuan dari uji ketepatan model adalah untuk mengetahui ketepatan dalam pemilihan metode dalam analisis faktor. Pada penelitian kali ini uji ketepatan metode dilakukan melalui persamaan RMSE (Root Mean Squared Error) berikut:

$$
R M S E=\sqrt{\frac{1}{\mathrm{n}}} \sum_{\mathrm{t}=\mathrm{h}}^{\mathrm{n}}\left(\mathrm{y}_{\mathrm{t}}-\mathrm{y}_{\mathrm{t}}^{\prime}\right)^{2}
$$

dengan $\mathrm{y}_{\mathrm{t}}-\mathrm{y}_{\mathrm{t}}{ }_{\mathrm{t}}$ merupakan nilai residual.

\section{HASIL DAN PEMBAHASAN}

\subsection{Uji Validitas dan Reliabilitas}

Untuk memastikan suatu instrumen dapat digunakan untuk pengambilan data, maka perlu dilakukan uji coba instrumen, dari data tersebut kemudian dilakukan uji validitas dan reliabilitas. Uji validitas dilakukan untuk mengetahui valid tidaknya pernyataan-pernyataan dalam kuesioner. Suatu kuesioner dikatakan valid jika nilai $r$ hitungnya lebih besar dari nilai $r$ tabel, Nilai $r$ tabel dapat dilihat dari daftar $r$ tabel signifikansi alpha $5 \%$ dengan mempertimbangkan jumlah sampel $n$ [10]. Dalam uji coba instrumen kali ini digunakan jumlah sampel sebanyak 30 dan nilai alpha 0,05 sehingga diperoleh nilai $r$ tabel 0,361. Adapun nilai $r$ hitung disajikan dalam Tabel 1, berikut:

Tabel 1. Nilai Uji Validitas

\begin{tabular}{ccccc}
\hline No & Variabel & r Tabel & r Hitung & \multirow{2}{*}{ Keterangan } \\
\hline $\mathbf{1}$ & Lingkungan alam & 0,361 & 0,920 & Valid \\
\hline $\mathbf{2}$ & Lingkungan sosial & 0,361 & 0,784 & Valid \\
\hline $\mathbf{3}$ & Kurikulum & 0,361 & 0,969 & Valid \\
\hline $\mathbf{4}$ & Program madrasah & 0,361 & 0,971 & Valid \\
\hline $\mathbf{5}$ & Sarana dan fasilitas & 0,361 & 0,960 & Valid \\
\hline $\mathbf{6}$ & Tenaga pengajar & 0,361 & 0,784 & Valid \\
\hline $\mathbf{7}$ & Kondisi fisiologis & 0,361 & 0,963 & Valid \\
\hline $\mathbf{8}$ & Kondisi panca indra & 0,361 & 0,892 & Valid \\
\hline $\mathbf{9}$ & Minat belajar & 0,361 & 0,553 & Valid \\
\hline $\mathbf{1 0}$ & Kecerdasan santri & 0,361 & 0,949 & Valid \\
\hline $\mathbf{1 1}$ & Bakat santri & 0,361 & 0,928 & Valid \\
\hline $\mathbf{1 2}$ & Motivasi santri & 0,361 & 0,920 & Valid \\
\hline $\mathbf{1 3}$ & Kemampuan kognitif & 0,361 & 0,960 & Valid \\
\hline
\end{tabular}

Berdasarkan tabel diatas dapat disimpulkan bahwa ke 13 variabel dinyatakan valid, karena memiliki nilai $\mathrm{r}$ hitung $>r$ tabel.

Uji reliabilitas menunjukkan sejauh mana suatu alat ukur dapat menghasilkan nilai yang sama jika dilakukan pengukuran kembali pada objek yang sama. Suatu kuesioner dikatakan reliabel jika memiliki nilai cronbach alpha $>0,6$ [14]. Berdasarkan perhitungan melalui Software SPSS 16.0 diperoleh nilai cronbach alpha $>0,6$, sehingga dapat dikatakan bahwa ke 13 variabel dinyatakan reliabel. 
Tabel 2. Reliability Statistic's

\begin{tabular}{cc}
\hline Cronbach's Alpha & Nof item \\
\hline 976 & 13 \\
\hline
\end{tabular}

\subsection{Uji Kelayakan Data}

Sebelum melakukan proses analisis faktor, terlebih dahulu perlu diketahui ada dan tidaknya korelasi antar variabel independent, sebab korelasi antar variabel independent merupakan prinsip dasar dalam proses analisis faktor. Uji kelayakan data dalam analisis faktor dilakukan melalui 3 uji, yaitu uji KMO (KeyserMayer Olkin), Uji MSA (Measure of Sampling Adequacy) dan Uji Bartlet Test of Sphrericity. Uji KMO (Keyser-Mayer Olkin) bertujuan untuk mengukur syarat kecukupan sampel dengan kriteria sampel dikatakan layak jika memiliki nilai $K M O>0,5$ [15]. Sedangkan uji Bartlett's Test of Sphericity bertujuan untuk menguji hipotesis bahwa matrik korelasi sederhana tidak berkorelasi didalam populasi. Kriteria pengujian Bartlett's Test of Sphericity adalah suatu data dikatakan tidak berkorelasi didalam populasi jika nilai $\chi^{2}$ hitung $>\chi^{2}$ tabel. Melalui pendekatan chi square diperoleh $\chi^{2}$ tabel sebesar 99,617. Berdasarkan persamaan (1) dan (3) hasil pengujian KMO (Keyser-Mayer Olkin) dan Bartlett's Test of Sphericity juga dapat dilihat pada output SPSS 16.0 berikut:

Tabel 3. KMO and Bartlett's Test

\begin{tabular}{|c|c|}
\hline Kaiser-Mayer-Olkin Measure Of Sampling Adequacy & 662 \\
\hline Bartlett's test of sphericity $\quad$ Approx. chi-square & 867.855 \\
\hline$d f$ & 78 \\
\hline sig & 000 \\
\hline
\end{tabular}

Selain melalui Uji KMO dan Uji Bartlett's Test of Sphericity, penentuan kelayakan sampel juga ditentukan melalui Uji MSA (Measure of Sampling Adequacy). Nilai MSA digunakan untuk mengukur kecukupan sampel dengan kriteria nilai $M S A \geq 0,5$ [15]. Berdasarkan persamaan (2) nilai Uji $M S A$ dapat diperoleh melalui perhitungan Tabel 4, berikut:

Tabel 4. Uji MSA (Measure of Sampling Adequacy)

\begin{tabular}{ccc}
\hline No & Variabel & r Hitung \\
\hline $\mathbf{1}$ & Lingkungan alam & 0,778 \\
\hline $\mathbf{2}$ & Lingkungan sosial & 0,5 \\
\hline $\mathbf{3}$ & Kurikulum & 0,657 \\
\hline $\mathbf{4}$ & Program madrasah & 0,784 \\
\hline $\mathbf{5}$ & Sarana dan fasilitas & 0,612 \\
\hline $\mathbf{6}$ & Tenaga pengajar & 0,523 \\
\hline $\mathbf{7}$ & Kondisi fisiologis & 0,680 \\
\hline $\mathbf{8}$ & Kondisi panca indra & 0,708 \\
\hline $\mathbf{9}$ & Minat belajar & 0,623 \\
\hline $\mathbf{1 0}$ & Kecerdasan santri & 0,806 \\
\hline $\mathbf{1 1}$ & Bakat santri & 0,697 \\
\hline $\mathbf{1 2}$ & Motivasi santri & 0,706 \\
\hline $\mathbf{1 3}$ & Kemampuan kognitif & 0,5 \\
\hline
\end{tabular}

Berdasarkan nilai diatas terbukti bahwa ke 13 variabel layak untuk diproses analisis faktor karena memiliki nilai MSA $>0,5$.

\subsection{Ekstraksi Faktor Metode Principal Axis Factoring}

Setelah variabel-variabel memenuhi syarat kelayakan untuk diproses analisis faktor, selanjutnya akan dilakukan proses inti dari analisis faktor yaitu melakukan proses ekstraksi faktor melalui metode Principal Axis Factoring. Berikut merupakan nilai komunalitas dengan menggunakan metode Principal Axis Factoring: 
Tabel 5. Nilai Komunalitas Metode Principal Axis Factoring

\begin{tabular}{ccccccc}
\hline Variabel & $\boldsymbol{\ell}^{\mathbf{2}}{ }_{\mathbf{1}}$ & $\boldsymbol{\ell}^{\mathbf{2}}{ }_{\mathbf{i} 2}$ & $\boldsymbol{\ell}^{\mathbf{2}}{ }_{\mathbf{i} 3}$ & $\boldsymbol{\ell}^{\mathbf{2}}{ }_{\mathbf{i} 4}$ & $\boldsymbol{\ell}^{\mathbf{2}}{ }_{\mathbf{i}}$ & $\mathbf{h}_{\mathbf{i}}{ }^{2 * *}$ \\
\hline $\mathbf{P 1}$ & 0.003 & 0.03 & $6.7 \times 10^{-6}$ & $4,5 \times 10^{-11}$ & $2.6 \times 10^{-21}$ & 0,453 \\
\hline $\mathbf{P 2 3}$ & 0.89 & 0.9 & 0.8 & 0.6 & 0.4 & 0,980 \\
\hline $\mathbf{P 4 9}$ & 0.02 & 0.02 & 0 & $1.8 \times 10^{-7}$ & $3.13 \times 10^{-14}$ & 0,707 \\
\hline $\mathbf{P 1 0 1 2}$ & 0.03 & 0.03 & 0 & $1.1 \times 10^{-6}$ & $1.15 \times 10^{-12}$ & 0,614 \\
\hline $\mathbf{P 1 3 1 5}$ & 0.02 & 0.02 & 0 & $6.9 \times 10^{-8}$ & $4.86 \times 10^{-15}$ & 0,637 \\
\hline $\mathbf{P 1 6 1 9}$ & 0.11 & 0.11 & 0.01 & 0 & $2.8 \times 10^{-8}$ & 0,989 \\
\hline $\mathbf{P 2 0 2 1}$ & 0.002 & 0.02 & $5 \times 10^{-6}$ & $2.1 \times 10^{-11}$ & $4.2 \times 10^{-22}$ & 0,853 \\
\hline $\mathbf{P 2 2}$ & 0.001 & 0.01 & $1.3 \times 10^{-6}$ & $1.6 \times 10^{-12}$ & $2.57 \times 10^{-24}$ & 0,965 \\
\hline $\mathbf{P 2 3 2 5}$ & 0.03 & 0.03 & 0 & $5.2 \times 10^{-7}$ & $2.7 \times 10^{-13}$ & 0,430 \\
\hline $\mathbf{P 2 6}$ & 0.01 & 0.01 & 0 & $3.2 \times 10^{-8}$ & $1.7 \times 10^{-15}$ & 0,519 \\
\hline $\mathbf{P 2 7}$ & 0.001 & 0 & 3.9 & $1.5 \times 10^{-13}$ & $2.2 \times 10^{-26}$ & 0,945 \\
\hline $\mathbf{P 2 8}$ & 0 & 0 & 1.9 & $3.6 \times 10^{-14}$ & $1.3 \times 10^{-27}$ & 0,932 \\
\hline $\mathbf{P 2 9 3 0}$ & 0.89 & 0.89 & 0.8 & 0.6 & 0.4 & 0,992 \\
\hline
\end{tabular}

\subsection{Penentuan Jumlah Faktor Metode Principal Axis Factoring}

Penentuan jumlah faktor dengan mempertimbangkan nilai eigen dapat dilakukan dengan melihat nilai eigen yang $\geq 1$. Melalui bantuan software SPSS 16.0 diperoleh nilai eigen berikut:

Tabel 6. Nilai Eigen

\begin{tabular}{cccc}
\hline Faktor & \multicolumn{3}{c}{ Initial Eigen Value } \\
\hline & Total & \% of Variance & Cumulative $\%$ \\
\hline $\mathbf{1}$ & 4,613 & 35,485 & 35,485 \\
\hline $\mathbf{2}$ & 2,054 & 15,797 & 51,282 \\
\hline $\mathbf{3}$ & 1,609 & 12,380 & 63,663 \\
\hline $\mathbf{4}$ & 1,338 & 10,290 & 73,953 \\
\hline $\mathbf{5}$ & 1,329 & 10,225 & 84,177 \\
\hline $\mathbf{6}$ & 0,658 & 5,062 & 89,240 \\
\hline $\mathbf{7}$ & 0,436 & 3,356 & 92,596 \\
\hline $\mathbf{8}$ & 0,359 & 2,765 & 95,361 \\
\hline $\mathbf{9}$ & 0,265 & 2,038 & 97,399 \\
\hline $\mathbf{1 0}$ & 0,221 & 1,699 & 99,098 \\
\hline $\mathbf{1 1}$ & 0,085 & 0,651 & 99,750 \\
\hline $\mathbf{1 2}$ & 0,021 & 0,162 & 99,912 \\
\hline $\mathbf{1 3}$ & 0,011 & 0,088 & 100,00 \\
\hline
\end{tabular}

Berdasarkan output diatas dapat diketahui bahwa terdapat 5 nilai eigen yang $\geq 1$. Dengan demikian dapat diketahui bahwa terdapat 5 faktor yang terbentuk.

\subsection{Rotasi Faktor Metode Principal Axis Factoring}

Rotasi faktor dilakukan untuk memperjelas tafsiran data yang diolah dengan analisis faktor. Rotasi faktor dilakukan jika masih terdapat variabel yang tidak memiliki perbedaan yang nyata dengan variabel lain, yaitu sama-sama memiliki nilai loding factor yang kurang dari 0,5 . Oleh karena itu perlu dilakukan rotasi faktor untuk memperjelas kedudukan variabel tersebut dalam faktor. Berikut merupakan hasil rotasi faktor orthogonal varimax pada metode Principal Axis Factoring: 
Tabel 7. Nilai Rotasi Faktor Metode Principal Axis Factoring

\begin{tabular}{cccccc}
\hline Variabel & Faktor 1 & Faktor 2 & Fakto 3 & Faktor 4 & Faktor 5 \\
\hline P1 & 0.552 & 0.125 & 0.077 & 0.258 & 0.245 \\
\hline P23 & 0.047 & 0.065 & 0.986 & 0.001 & 0.027 \\
\hline P49 & 0.207 & 0.157 & 0.001 & 0.794 & 0.098 \\
\hline P1012 & 0.504 & 0.075 & 0.029 & 0.448 & 0.391 \\
\hline P1315 & 0.068 & 0.189 & 0.019 & 0.772 & 0.02 \\
\hline P1619 & -0.042 & 0.023 & 0.05 & 0.093 & 0.988 \\
\hline P2021 & 0.221 & 0.850 & 0.086 & 0.113 & 0.249 \\
\hline P22 & 0.94 & 0.269 & 0.009 & 0.01 & 0.014 \\
\hline P2325 & 0.163 & 0.229 & -0.002 & 0.022 & 0.593 \\
\hline P26 & 0.37 & 0.499 & 0.109 & 0.318 & -0.143 \\
\hline P27 & 0.196 & 0.921 & 0.036 & 0.195 & 0.139 \\
\hline P28 & 0.927 & 0.259 & 0.010 & 0.068 & -0.009 \\
\hline P2930 & 0.028 & 0.070 & 0.993 & 0.0001 & -0.013 \\
\hline
\end{tabular}

\subsection{Interpretasi Faktor Metode Principal Axis Factoring}

Interpretasi faktor dilakukan dengan cara melihat nilai loading factor setiap variabel terhadap faktor. Variabel yang memiliki nilai loading factor tertinggi pada faktor yang sama, maka variabel tersebut merupakan bagian dari faktor tersebut. Berdasarkan nilai loading factor maka dapat diperoleh interpretasi faktor sebagai berikut:

Tabel 8. Interpretasi Faktor

\begin{tabular}{|c|c|c|c|c|}
\hline Faktor & Variabel & Loading Factor & Nilai Eigen & Variansi \\
\hline \multirow{4}{*}{ Faktor 1} & $\mathrm{P} 1$ & 0,552 & \multirow{4}{*}{4,613} & \multirow{4}{*}{35,485} \\
\hline & P1012 & 0,504 & & \\
\hline & P22 & 0,940 & & \\
\hline & P28 & 0,927 & & \\
\hline \multirow{3}{*}{ Faktor 2} & P2021 & 0,850 & \multirow{3}{*}{2,054} & \multirow{3}{*}{15,787} \\
\hline & $\mathrm{P} 26$ & 0,499 & & \\
\hline & $\mathrm{P} 27$ & 0,921 & & \\
\hline \multirow{2}{*}{ Faktor 3} & $\mathrm{P} 23$ & 0,986 & \multirow{2}{*}{1.609} & \multirow{2}{*}{12,380} \\
\hline & P2930 & 0,993 & & \\
\hline \multirow{2}{*}{ Faktor 4} & P49 & 0,794 & \multirow{2}{*}{1,338} & \multirow{2}{*}{10,290} \\
\hline & P1315 & 0,772 & & \\
\hline \multirow{2}{*}{ Faktor 5} & P1619 & 0,988 & \multirow{2}{*}{1,329} & \multirow{2}{*}{10,225} \\
\hline & $\mathrm{P} 2325$ & 0,593 & & \\
\hline
\end{tabular}

\subsection{Penamaan Faktor Metode Principal Axis Factoring}

Pada penelitian kali ini penamaan faktor dilakukan dengan melihat nilai loading factor tertinggi dalam suatu faktor.

1. Faktor 1 yang terdiri dari variabel lingkungan alam, program madrasah, kondisi panca indra dan motivasi santri diberi nama kondisi panca indra, sebab variabel ini memiliki loading factor tertinggi dari pada faktor lain yang masuk pada faktor 1 .

2. Faktor 2 yang terdiri dari variabel kondisi fisiologis, kecerdasan santri, dan bakat santri diberi nama bakat santri, sebab variabel ini memiliki nilai loading factor yang lebih tinggi dari yang lain.

3. Faktor 3 yang terdiri dari variabel lingkungan sosial dan kemampuan kognitif diberi nama kemampuam kognitif sebab kemampuan kognitif memiliki nilai loading factor yang lebih tinggi dari yang lain yang masuk pada faktor 3 .

4. Faktor 4 yang terdiri dari variabel kurikulum dan sarana dan fasilitas diberi nama faktor kurikulum sebab variabel ini memiliki nilai loading factor yang lebih tinggi dari yang lain yang masuk pada faktor 4.

5. Faktor 5 yang terdiri dari variabel tenaga pengajar dan minat belajar diberi nama faktor tenaga pengajar, sebab variabel ini memiliki nilai loading factor yang lebih tinggi dari yang lain yang masuk pada faktor 5 . 


\section{8. $\quad$ Ekstraksi Faktor Maximum Likelihood}

Setelah variabel-variabel memenuhi syarat kelayakan untuk diproses analisis faktor, selanjutnya akan dilakukan proses inti dari analisis faktor yaitu melakukan proses ekstraksi faktor melalui metode Maximum Likelihood. Berikut merupakan nilai komunalitas dengan menggunakan metode Maximum Likelihood:

Tabel 9. Nilai Komunalitas Metode Maximum Likelihood

\begin{tabular}{|c|c|c|c|c|c|c|}
\hline Variabel & $\boldsymbol{\ell}_{\mathrm{i} 1}^{2}$ & $\ell^{2}{ }_{12}$ & $\ell^{2}{ }_{i 3}$ & $\ell^{2}{ }_{i 4}$ & $\ell^{2}{ }_{i 5}$ & $\mathbf{h}_{\mathbf{i}}^{2 * *}$ \\
\hline P1 & 0.003 & 0.03 & $6.7 \times 10^{-6}$ & $4,5 \times 10^{-11}$ & 2. $6 \times 10^{-21}$ & 0,453 \\
\hline P23 & 0.89 & 0.9 & 0.8 & 0.6 & 0.4 & 0,980 \\
\hline P49 & 0.02 & 0.02 & 0 & $1.8 \times 10^{-7}$ & $3.13 \times 10^{-14}$ & 0,707 \\
\hline P1012 & 0.03 & 0.03 & 0 & $1.1 \times 10^{-6}$ & $1.15 \times 10^{-12}$ & 0,614 \\
\hline P1315 & 0.02 & 0.02 & 0 & $6.9 \times 10^{-8}$ & $4.86 \times 10^{-15}$ & 0,637 \\
\hline P1619 & 0.11 & 0.11 & 0.01 & 0 & $2.8 \times 10^{-8}$ & 0,989 \\
\hline P2021 & 0.002 & 0.02 & $5 \times 10^{-6}$ & $2.1 \times 10^{-11}$ & $4.2 \times 10^{-22}$ & 0,853 \\
\hline $\mathbf{P 2 2}$ & 0.001 & 0.01 & $1.3 \times 10^{-6}$ & $1.6 \times 10^{-12}$ & $2.57 \times 10^{-24}$ & 0,965 \\
\hline $\mathbf{P 2 3 2 5}$ & 0.03 & 0.03 & 0 & $5.2 \times 10^{-7}$ & $2.7 \times 10^{-13}$ & 0,430 \\
\hline P26 & 0.01 & 0.01 & 0 & $3.2 \times 10^{-8}$ & $1.7 \times 10^{-15}$ & 0,519 \\
\hline P27 & 0.001 & 0 & 3.9 & $1.5 \times 10^{-13}$ & $2.2 \times 10^{-26}$ & 0,945 \\
\hline P28 & 0 & 0 & 1.9 & $3.6 \times 10^{-14}$ & $1.3 \times 10^{-27}$ & 0,932 \\
\hline P2930 & 0.89 & 0.89 & 0.8 & 0.6 & 0.4 & 0,992 \\
\hline
\end{tabular}

\subsection{Penentuan Jumlah Faktor Maximum Likelihood}

Penentuan jumlah faktor dengan mempertimbangkan nilai eigen dapat dilakukan dengan melihat nilai eigen value yang $\geq 1$. Melalui bantuan software SPSS 16.0 diperoleh nilai eigen berikut:

Tabel 10. Nilai Eigen Metode Maximum Likelihood

\begin{tabular}{cccc}
\hline Faktor & \multicolumn{3}{c}{ Initial Eigen Value } \\
\hline 1 & Total & \% of Variance & Cumulative \% \\
\hline 2 & 4,613 & 35,485 & 35,485 \\
\hline 3 & 2,054 & 15,797 & 51,282 \\
\hline 4 & 1,609 & 12,380 & 63,663 \\
\hline 5 & 1,338 & 10,290 & 73,953 \\
\hline 6 & 1,329 & 10,225 & 84,177 \\
\hline 7 & 0,658 & 5,062 & 89,240 \\
\hline 8 & 0,436 & 3,356 & 92,596 \\
\hline 9 & 0,359 & 2,765 & 95,361 \\
\hline 10 & 0,265 & 2,038 & 97,399 \\
\hline 11 & 0,221 & 1,699 & 99,098 \\
\hline 12 & 0,085 & 0,651 & 99,750 \\
\hline 13 & 0,021 & 0,162 & 99,912 \\
\hline
\end{tabular}

Berdasarkan output diatas dapat diketahui bahwa terdapat 5 nilai eigen yang $\geq 1$. Dengan demikian dapat diketahui bahwa terdapat 5 faktor yang terbentuk.

\subsection{Rotasi Faktor Maximum Likelihood}

Rotasi faktor dilakukan untuk memperjelas tafsiran data yang diolah dengan analisis faktor. Rotasi faktor dilakukan jika masih terdapat variabel yang tidak memiliki perbedaan yang nyata dengan variabel lain, yaitu sama-sama memiliki nilai loading factor yang kurang dari 0,5. Oleh karena itu perlu dilakukan rotasi faktor untuk memperjelas kedudukan variabel tersebut dalam faktor. Berikut merupakan hasil rotasi faktor orthogonal varimax pada Metode Maximum Likelihood. 
Tabel 11. Nilai Rotasi Faktor Metode Maximum Likelihood

\begin{tabular}{cccccc}
\hline Variabel & Faktor 1 & Faktor 2 & Faktor 3 & Faktor 4 & Faktor 5 \\
\hline P1 & 0.495 & 0.146 & 0.081 & 0.258 & -0.292 \\
\hline P23 & 0.048 & 0.062 & 0.984 & 0.001 & 0.02 \\
\hline P49 & 0.189 & 0.158 & -0.004 & 0.794 & 0.077 \\
\hline P1012 & 0.422 & 0.019 & 0.027 & 0.448 & 0.376 \\
\hline P1315 & 0.064 & 0.195 & 0.011 & 0.772 & 0.041 \\
\hline P1619 & 0.076 & 0.031 & 0.054 & 0.093 & 0.981 \\
\hline P2021 & 0.215 & 0.829 & 0.086 & 0.113 & 0.228 \\
\hline P22 & 0.955 & 0.254 & 0.013 & 0.1 & 0.039 \\
\hline P2325 & 0.197 & 0.183 & 0.003 & 0.022 & 0.622 \\
\hline P26 & 0.35 & 0.526 & 0.097 & 0.318 & 0.134 \\
\hline P27 & 0.181 & 0.956 & 0.031 & 0.195 & 0.146 \\
\hline P28 & 0.945 & 0.245 & 0.015 & 0.068 & -0.019 \\
\hline P2930 & 0.025 & 0.074 & 0.997 & 0.0003 & 0.012 \\
\hline
\end{tabular}

\subsection{Interpretasi Faktor Maximum Likelihood}

Interpretasi faktor dilakukan dengan cara melihat nilai loading factor setiap variabel terhadap faktor. Variabel yang memiliki nilai loading factor tertinggi pada faktor yang sama, maka variabel tersebut merupakan bagian dari faktor tersebut. Berdasarkan nilai loading factor maka dapat diperoleh interpretasi faktor sebagai berikut:

Tabel 12. Interpretasi Faktor Metode Maximum Likelihood

\begin{tabular}{|c|c|c|c|c|}
\hline Faktor & Variabel & Loading Faktor & Nilai Eigen & Variansi \\
\hline \multirow{3}{*}{ Faktor 1} & P1 & 0,495 & \multirow{3}{*}{4,613} & \multirow{3}{*}{35,485} \\
\hline & P22 & 0,955 & & \\
\hline & P28 & 0,945 & & \\
\hline \multirow{3}{*}{ Faktor 2} & P2021 & 0,829 & \multirow{3}{*}{2,054} & \multirow{3}{*}{15,787} \\
\hline & $\mathrm{P} 26$ & 0,526 & & \\
\hline & $\mathrm{P} 27$ & 0,956 & & \\
\hline \multirow{2}{*}{ Faktor 3} & P23 & 0,984 & \multirow{2}{*}{1.609} & \multirow{2}{*}{12,380} \\
\hline & P2930 & 0,997 & & \\
\hline \multirow{3}{*}{ Faktor 4} & P49 & 0,819 & \multirow{3}{*}{1,338} & \multirow{3}{*}{10,290} \\
\hline & P1012 & 0,458 & & \\
\hline & P1315 & 0,763 & & \\
\hline \multirow{2}{*}{ Faktor 5} & P1619 & 0,988 & \multirow{2}{*}{1,329} & \multirow{2}{*}{10,225} \\
\hline & P2325 & 0,593 & & \\
\hline
\end{tabular}

\subsection{Penamaan Faktor Maximum Likelihood}

Pada penelitian kali ini penamaan faktor dilakukan dengan melihat nilai loading factor tertinggi dalam suatu faktor.

1. Faktor 1 yang terdiri dari variabel lingkungan alam, kondisi panca indra, dan motivasi santri, faktor ini diberi nama faktor kondisi panca indra, sebab variabel ini memiliki loading factor tertinggi dari pada faktor lain yang masuk pada faktor 1 .

2. Faktor 2 yang terdiri dari variabel kondisi fisiologis, kecerdasan santri, dan bakat santri, faktor ini diberi nama faktor bakat santri, sebab variabel ini memiliki nilai loading factor yang lebih tinggi dari yang lain.

3. Faktor 3 yang terdiri dari variabel lingkungan sosial dan kemampuan kognitif, faktor ini diberi nama faktor kemampuan kognitif, sebab kemampuan kognitif memiliki nilai loading factor yang lebih tinggi dari yang lain yang masuk pada faktor 3 .

4. Faktor 4 yang terdiri dari variabel sarana dan fasilitas, kurikulum, dan program madrasah, faktor ini diberi nama faktor sarana dan fasilitas,sebab variabel ini memiliki nilai loading factor yang lebih tinggi dari yang lain yang masuk pada faktor 4 .

5. Faktor 5 yang terdiri dari variabel tenaga pengajar dan minat belajar, faktor ini diberi nama faktor tenaga pengajar sebab variabel ini memiliki nilai loading factor yang lebih tinggi dari yang lain yang masuk pada faktor 5 . 


\subsection{Penamaan Uji Ketepatan Metode}

Tujuan dari uji ketepatan metode ini adalah untuk menentukan metode ekstraksi mana yang lebih tepat digunakan dalam analisis faktor. Ketepatan dalam pemilihan metode dalam analisis faktor dilakukan dengan melihat selisih nilai residual dari masing-masing metode. Berikut merupakan nilai residual dari kedua metode:

Tabel 13. Nilai Residual

\begin{tabular}{cc}
\hline Principal Axis Factoring & Maximum likelihood \\
\hline 0,00035 & 0,00 \\
\hline-0.00004 & 0,00 \\
\hline$-0,00041$ & 0,00 \\
\hline 0,00010 & 0,00 \\
\hline 0,00015 & 0,00 \\
\hline 0,00008 & 0,00 \\
\hline$-0,00016$ & 0,00 \\
\hline 0,00011 & 0,00 \\
\hline$-0,00019$ & 0,00 \\
\hline 0,00024 & 0,00 \\
\hline 0,00011 & 0,00 \\
\hline$-0,00034$ & 0,00 \\
\hline$-0,00001$ & 0,00 \\
\hline
\end{tabular}

Melalui persamaan (9) diperoleh nilai RMSE untuk metode Principal Axis Factoring adalah sebagai berikut:

$$
\begin{aligned}
& R M S E=\sqrt{\frac{1}{\mathrm{n}}} \sum_{\mathrm{t}=\mathrm{h}}^{\mathrm{n}}\left(\mathrm{y}_{\mathrm{t}}-\mathrm{y}_{\mathrm{t}}^{\prime}\right)^{2} \\
& R M S E=\sqrt{\frac{1}{75}}(0,00035)^{2}+(-0.00004)^{2}+(-0,00041)^{2}+(0,00010)^{2}+(0,00015)^{2}+(0,00008)^{2}+ \\
& (-0,00016)^{2}+(0,00011)^{2}+(-0,00019)^{2}+(0,00024)^{2}+(0,00011)^{2}+(-0,00034)^{2}+(-0,00001)^{2} \\
& R M S E=7,8687 \times 10^{-7}
\end{aligned}
$$

Sedangkan nilai residual untuk metode Maximum Likelihood adalah sebagai berikut:

$$
\begin{aligned}
R M S E= & \sqrt{\frac{1}{\mathrm{n}}} \sum_{\mathrm{t}=\mathrm{h}}^{\mathrm{n}}\left(\mathrm{y}_{\mathrm{t}}-\mathrm{y}_{\mathrm{t}}^{\prime}\right)^{2} \\
R M S E= & \sqrt{\frac{1}{75}}(0,000)^{2}+(0,000)^{2}+(0,000)^{2}+(0,000)^{2}+(0,000)^{2}+(0,000)^{2}+(0,000)^{2}+(0,000)^{2}+(0,000)^{2} \\
& +(0,000)^{2}+(0,000)^{2}(0,000)^{2}+(0,000)^{2} \\
R M S E= & 0
\end{aligned}
$$

Berdasarkan kedua perhitungan diatas diperoleh nilai residual metode Principal Axis Factoring yang lebih besar dari metode Maximum Likelihood.

\section{KESIMPULAN}

Pada Uji ketepatan model dengan rumus Root Mean Squared Error (RMSE) diperoleh hasil bahwa nilai $R M S E$ untuk metode Principal Axis Factoring adalah $7,8687 \times 10^{-7}$, sedangkan nilai $R M S E$ untuk metode Maximum Likelihood adalah 0, dengan kriteria ketepatan model diperoleh jika suatu metode memiliki nilai $R M S E$ lebih kecil maka dapat disimpulkan bahwa metode yang paling tepat digunakan adalah metode Maximum Likelihood.

\section{DAFTAR PUSTAKA}

[1] I. Fauzi, "Model Pembelajaran Kitab Al-Jurumiyah Di Pondok Pesantren Wali Songo Desa Sukajadi Kecamatan Bumiratu Nuban Lampung Tengah Tahun Pelajaran 2016/2017,” 2017.

[2] L. Dodi, "Pengajaran Nahwu Shorof (Ber-Kaca Dari Pengalaman Pesantren)," Tafaqquh, vol. 1, no. 1, pp. 100-122, 2013.

[3] dania puspitasari nur ida yesinia, norita citra yuliarti, “Analisis Faktor yang Mempengaruhi Akuntabilitas Pengelolaan Alokasi Dana Desa Sistem Pengendalian Internal juga Pengelolaan Keuangan Desa ialah,” vol. 10, no. 1, pp. 105-112, 2018.

[4] R. E. D. Nadeak, "Aplikasi Principal Component Analysis Dan Maximum Likelihood Estimation Dalam Analisis Faktor Yang 
Memengaruhi Pemilihan Metode Kontrasepsi Suntik Di Desa Pulau Halang Muka Kecamatan Kubu Babussalam,” 2016.

[5] A. B. Hafilda, "Penerapan Analisis Faktor Eksploratori Untuk Mengetahui Faktor - Faktor Yang Dipertimbangkan Dalam Menentukan Kepuasan Pengguna Mobile Banking," 2017.

[6] H. Wahyuningsih, D. Rahayu, and S. Pertiwi, "Adaptasi Sanctification of Marriage Questionnaire: Versi Indonesia untuk Masyarakat Muslim Adaptation of Sanctification of Marriage Questionnaire : Indonesian Version for Muslim Communities," vol. 26, pp. 217-232, 2021, doi: 10.20885/psikologika.vol26.iss1.art11.

[7] M. Maulidia, "Analisis Faktor-Faktor Yang Mempengaruhi Perilaku Konsumen Dalam Keputusan Pembelian Pakaian Muslimah Di Banda Aceh (Studi Kasus Di Pasar Aceh)," 2019.

[8] D. R. Diva, D. Rachmatin, and E. Nurlaelah, "Analisis Data Kualitas Jasa terhadap Kepuasan Pelanggan K-Pop Concert Organizer Mecimapro dengan Analisis Faktor,” Eureka Matika, vol. 6, no. 2, pp. 36-51, 2018.

[9] I. Nailinni'mah, Analisis Faktor-Faktor Yang Mempengaruhi Loyalitas Nasabah Dalam Menabung Di Bri Syariah Kcp Ponorogo. 2020.

[10] N. W. Switrayni, D. Komalasari, and N. Fitriyani, “Analisis Rotasi Ortogonal pada Teknik Analisis Faktor Menggunakan Metode," Eig. Math., vol. 03, no. 01, pp. 45-55, 2020.

[11] D. Ratnasari, “Analisis Pengaruh Kualitas Pelayanan, Harga Dan Promosi Terhadap Kepuasan Konsumen Go-Jek,” 2020.

[12] Ani Priyana Yuliawati, "Analisis faktor-faktor yang mempengaruhi kepuasan nasabah dalam pelayanan di bank muamalat kcp ponorogo skripsi,” 2019.

[13] A. Nuciffera, "Analisis faktor yang mempengaruhi kesejahteraan masyarakat di pulau jawa dengan menggunakan principal component analysis dan common factor analysis," 2019.

[14] Nurjannah, "Analisis Faktor-Faktor Yang Mempengaruhi Keputusan Konsumen Dalam Menggunakan Ponsel Gsm Tipe Qwerty," 2010.

[15] A. Rahim, "Penentuan Faktor Yang Mempengaruhi Tingkat Kecelakaan Lalu Lintas Di Kota Medan Dengan Metode Analisis Faktor," 2016. 
